\title{
A study of knowledge and attitude about eye donation among 1st- year medical students
}

\author{
Gotekar R. ${ }^{\mathbf{1}}$, K. Joshi A. ${ }^{2 *}$ \\ DOI: https://doi.org/10.17511/jooo.2020.i02.01 \\ ${ }^{1}$ Rajesh Gotekar, Associate Professor, Department of Ophthalmology, Bharati Vidyapeeth (Deemed to be University) Medical College and \\ Hospital, Sangli, Maharashtra, India. \\ 2* Ajit K. Joshi, Professor and Head, Department of Ophthalmology, Bharati Vidyapeeth (Deemed to be University) Medical College and \\ Hospital, Sangli, Maharashtra, India.
}

Introduction: Corneal transplantation for sight restoration is the only treatment modality available for those who are blind from corneal diseases. Medical students, as future doctors of the society, can be an effective tool for planning, educating, sensitizing, motivating the general public to pledge for eye donation. For this purpose, an assessment of the knowledge and awareness about eye donation among medical students is important. Materials and Methods: The study was conducted at Bharati Vidyapeeth Deemed to be University medical college and hospital, Sangli. The students admitted for the first year MBBS were enrolled for a pretested, questionnaire to collect data validating their knowledge and awareness about eye donation, sources of information about eye donation, reason/s for willingness and reason/s for non-willingness to donate eye/s. A total of 137 students participated in the study. Results: In this study 71 (51.72 \%) participant students had a knowledge that the ideal time of eye removal was within 6 hours of death. 120 (87.59\%) participants expressed their will for eye donation. Perceived reasons for not pledging eyes by the students $17(12.40 \%)$ felt, eye donation was against their religious belief $03(2.1 \%)$, fear of misuse of eyes, $24(17.51 \%)$ and 15 $(10.94 \%)$ do not wish to be mutilated. Conclusion: This study revealed that all first-year MBBS student participants are well aware of eye donations and120 (87.59\%) are willing to pledge for eye donation.

Keywords: Awareness Corneal blindness, Donor Keratoplasty, MBBS student

Corresponding Author

Ajit K. Joshi, Professor and Head, Department of Ophthalmology, Bharati Vidyapeeth (Deemed to be University) Medical College and Hospital, Sangli, Maharashtra, India.

Email: ajit_jshi@rediffmail.com
How to Cite this Article

To Browse

Gotekar R, Joshi AK. A study of knowledge and attitude about eye donation among 1st-year medical students. Trop J Ophthalmol Otolaryngol. 2020;5(2):39-46. Available From https://opthalmology.medresearch.in/index.php/jooo /article/view/129

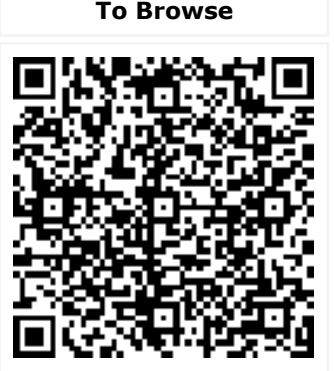

\begin{tabular}{|c|c|c|c|c|}
\hline \multirow{2}{*}{\multicolumn{2}{|c|}{$\begin{array}{c}\text { Manuscript Received } \\
2020-01-25 \\
\text { Conflict of Interest } \\
\text { No }\end{array}$}} & $\begin{array}{c}\text { Review Round } 1 \\
2020-02-04\end{array}$ & $\begin{array}{c}\text { Review Round } 2 \\
2020-02-09\end{array}$ & Review Round 3 \\
\hline & & $\begin{array}{c}\text { Funding } \\
\mathrm{Nil}\end{array}$ & $\begin{array}{c}\text { Ethical Approval } \\
\text { Yes }\end{array}$ & $\begin{array}{c}\text { Plagiarism X-checker } \\
6 \%\end{array}$ \\
\hline OPEN & (c) 2020 by & \multicolumn{3}{|c|}{$\begin{array}{l}\text { (c) } 2020 \text { by Rajesh Gotekar, Ajit K. Joshi and Published by Siddharth Health Research and Social Welfare Society. This is an } \\
\text { Open Access article licensed under a Creative Commons Attribution } 4.0 \text { International License } \\
\text { https://creativecommons.org/licenses/by/4.0/ unported [CC BY 4.0]. }\end{array}$} \\
\hline
\end{tabular}




\section{Introduction}

Corneal diseases constitute a significant cause of visual impairment and curable blindness worldwide, especially in developing countries like India $[1,2]$. The visual impairment study (2010) estimated that 285 million people are visually impaired, out of which 39 million people are blind [3]. Corneal blindness accounts for $12 \%$ of the global blindness and the majority population of the corneal blind is from India $[4,5]$. The waiting list for corneal transplants is huge. Therefore, in India, it is the need of the hour to increase awareness about eye donation for the procurement of donor corneas. The first corneal transplantation took place successfully in India in 1948 [6] Corneal transplantation for sight restoration is the available treatment modality for the corneal blind from corneal diseases. Advanced surgical technology has improved the success rate of corneal transplants to approximately $95 \%$. The statistics on eye donation in India shows that there is a considerable and constantly growing backlog of corneal transplantation. A large proportion of corneal blindness is curable [7]. Eye donation, an act of charity, is totally voluntary and purely for the benefit of society. Even after death, the donor lives in the eyes of the recipient. Corneas retrieved from a dead person can be utilized for more than one corneal blind for the restoration of sight of more than one corneal blind, apart from its use in research [8].

As future doctors, medical students can take up the role of promoting eye donation by planning, educating, sensitizing, and motivating the general public to pledge for eye donation. But because these newly admitted medical students may lack relevant basic knowledge, information about eye donation and are influenced by personal attitudes, and biases $[9,10]$. For this reason, the assessment of their knowledge and awareness about eye donation is very crucial.

\section{Materials and Methods}

Setting: All the freshly admitted students for the first year of MBBS in the Academic year 2019 batch of Bharati Vidyapeeth (Deemed to be University) Medical College and Hospital, Sangli were enrolled (150 students) after explaining the purpose of the study.

Duration of Study: 2 months (1st December 201931st January 2020)
Type of Study: Descriptive Observational Study

Sampling Method: Purposive method.

Sample size: 150 Medical Students of first-year MBBS, admission year2019

\section{Inclusion Criteria:}

- All the students enrolled for the first-year MBBS in the year 2019.

- Those students completed 18 years of age

\section{Exclusion Criteria:}

- Those students who are not willing to consent

- Those students below 18 years of age

Data Collection Procedure: A time period of 20 minutes was given to each student for filling up of the proforma. Written informed consent was obtained from all of the freshly admitted first-year MBBS students who completed 18 years of age of 2019 batch. At the time of the test, a total of 137 students out of 150 were present. 70 male students and 67 female students wrote voluntarily the pretested questionnaire. A pretested, semi-structured questionnaire was self-administered for collecting necessary information.

The questionnaire contained questions about knowledge and awareness of eye donation, on demographic details, source of information, their reasons for willingness and no-willingness to donate eyes. The collected data was kept confidential to the project Data analysis; a Total of 137 students attended the test. 70 male students 67 female students wrote voluntarily the pre-tested questionnaire. Data compiled in MS-Excel sheet and responses given to the questions calculated in percentage.

Ethical consideration and permission: Ethical permission from the institutional ethics committee of Bharati Vidyapeeth Deemed to be University medical college and hospital, Sangli, with approval letter BV (DU) MC and H Sangli/ IEC/373/19

Scoring system: Not applicable

The surgical procedure involved: Nil

Table-1: Gender wise students $(n=137)$.

\begin{tabular}{|c|c|c|}
\hline No. of Male students & No. of Female Students & Total \\
\hline & 67 & 137 \\
\hline
\end{tabular}

Table-2: Information given regarding eye donation: $(n=137)$.

\begin{tabular}{|l|l|l|}
\hline Eye donation & No. of Students giving the Responses & $\%$ of students \\
\hline
\end{tabular} 
Gotekar R. et al: A study of knowledge and attitude about eye

\begin{tabular}{|l|l|l|l|}
\hline Source of information from & Newspaper & 32 & $23.35 \%$ \\
\cline { 2 - 4 } & Television & 33 & $24.08 \%$ \\
\cline { 2 - 4 } & Internet & 38 & $27.73 \%$ \\
\hline
\end{tabular}

\begin{tabular}{|l|l|l|}
\hline Health Professionals & 35 & $25.54 \%$ \\
\hline Nothing particular source & 30 & $21.89 \%$ \\
\hline
\end{tabular}

Table-3: Responses given to questionnaire- knowledge about eye donation $(n=137)$

\begin{tabular}{|c|c|c|c|}
\hline Details of Questions & $\begin{array}{l}\text { The response was given for } \\
\text { the Question }\end{array}$ & $\begin{array}{l}\text { No. of } \\
\text { students }\end{array}$ & $(\%)$ \\
\hline 1\} Knows what is the exact meaning of "Keratoplasty" & $\begin{array}{l}\text { Yes } \\
\text { No }\end{array}$ & 77 & $\begin{array}{l}56.20 \% \\
44.52 \%\end{array}$ \\
\hline 2\} Knows a single eye can be used for multiple recipients & Yes & 78 & $42.33 \%$ \\
\hline $\begin{array}{l}\text { 3\} Knows what to do for the protection of eyes after the death of a relative after informing to } \\
\text { Eye Bank for eye donation purposes. }\end{array}$ & Yes & 71 & $\begin{array}{l}51.72 \% \\
46.71 \%\end{array}$ \\
\hline $\begin{array}{l}\text { 4\} Knows the time interval within which eyes should be removed from the donor after his/her } \\
\text { death for its proper use }\end{array}$ & Yes & 71 & $\begin{array}{l}51.82 \% \\
47.44 \%\end{array}$ \\
\hline 5\} Knows whether Eye donation disfigures or not disfigures the face of the donor & $\begin{array}{l}\text { Yes } \\
\text { No }\end{array}$ & $\begin{array}{l}28 \\
110\end{array}$ & $\begin{array}{l}20.43 \% \\
80.29 \%\end{array}$ \\
\hline $\begin{array}{l}\text { 6\} The family of a deceased person can pledge his/her eyes for donation even if the person has } \\
\text { not signed a will }\end{array}$ & $\begin{array}{l}\text { True } \\
\text { False }\end{array}$ & 75 & $36.49 \%$ \\
\hline 7\} Knows what is the meaning of "Enucleation " & $\begin{array}{l}\text { A) Complete removal of the } \\
\text { eyeball } \\
\text { B) Only cornea } \\
\text { C) Only sclera }\end{array}$ & $\begin{array}{l}64 \\
49 \\
22\end{array}$ & $\begin{array}{l}46.71 \% \\
35.76 \% \\
16.05 \%\end{array}$ \\
\hline 8\} What can be transplanted to the recipient from donated eyes? & $\begin{array}{l}\text { a) Cornea } \\
\text { b) Retina \&Lens } \\
\text { c) Complete eyeball } \\
\text { d) Don't know }\end{array}$ & $\begin{array}{l}48 \\
32 \\
35 \\
32\end{array}$ & \begin{tabular}{|l|}
$35.03 \%$ \\
$23.35 \%$ \\
$25.54 \%$ \\
$23.35 \%$
\end{tabular} \\
\hline 9\} Knows who will be the best to promote Eye Donation among the general public? & $\begin{array}{l}\text { a) Hospital administration } \\
\text { b) Health care providers } \\
\text { c) Govt. } \\
\text { d) NGOs }\end{array}$ & $\begin{array}{l}30 \\
48 \\
65 \\
31\end{array}$ & $\begin{array}{l}21.89 \% \\
35.03 \% \\
47.44 \% \\
22.62 \% \\
\end{array}$ \\
\hline 10\} A single eye donation can be used for multiple recipients. & $\begin{array}{l}\text { a) True } \\
\text { b) False }\end{array}$ & 78 & $\begin{array}{l}42.33 \% \\
52.55 \%\end{array}$ \\
\hline
\end{tabular}

Table-4: Responses given to questionnaire- Awareness about eye donation $(n=137)$

\begin{tabular}{|l|l|l|l|}
\hline \multicolumn{1}{|c|}{ Awareness about Eye Donation } & \multicolumn{1}{|c|}{$\begin{array}{c}\text { Response } \\
\text { Given }\end{array}$} & \multicolumn{1}{|c|}{$\begin{array}{c}\text { Nof } \\
\text { students }\end{array}$} & \\
\hline Are they aware of organ donation legislation act & Yes & 77 & $56.20 \%$ \\
& No & 59 & $43.06 \%$ \\
\hline Is there is a feeling of necessity to promote eye donation & Yes & 105 & $76.64 \%$ \\
& No & 03 & $2.1 \%$ \\
Are they aware of the shortage of eye donation/s in India & Yes & 128 & $20.43 \%$ \\
\hline
\end{tabular}

Table-5: Number of students pledging for and non-pledging for eye donation $(n=137)$.

\begin{tabular}{|l|l|c|}
\hline & Number of students & $(\%)$ \\
\hline Students pledging for Eye Donation? & 120 & $(87.59 \%)$ \\
\hline Students not pledging for Eye Donation? & 17 & $(12.40 \%)$ \\
\hline
\end{tabular}

Table-6: Reasons given for willingness to donate Eyes $(n=137)$

\begin{tabular}{|l|l|l|}
\hline & \multicolumn{1}{|c|}{$\begin{array}{c}\text { No. of } \\
\text { responses }\end{array}$} & (\%) \\
\hline $\begin{array}{l}\text { A) Would like something positive to come from } \\
\text { my death }\end{array}$ & 85 & $62.04 \%$ \\
\hline B) Can continue to live even after my death & 26 & $18.97 \%$ \\
\hline C) My religion supports organ donation & 03 & $2.1 \%$ \\
\hline D)Social commitment & 15 & $10.94 \%$ \\
\hline
\end{tabular}


Table-7: Reasons given for not willing to donate eyes ( 42 responses)

\begin{tabular}{|l|l|l|}
\hline & \multicolumn{1}{|c|}{$\begin{array}{c}\text { No. of } \\
\text { responses }\end{array}$} & (\%) \\
\hline A) It is against my religious belief & 03 & $2.1 \%$ \\
\hline $\begin{array}{l}\text { B) I fear to donate eyes may/might be } \\
\text { misused }\end{array}$ & 24 & $17.51 \%$ \\
\hline $\begin{array}{l}\text { C)I live far away from the closet center of eye } \\
\text { bank }\end{array}$ & 00 & 00 \\
\hline D)I Do not wish to be mutilated & 15 & $10.94 \%$ \\
\hline
\end{tabular}

Medical students of first MBBS were assessed for their awareness and knowledge on eye donation. A total of 137 students attended the test .70 male students 67 female students wrote voluntarily the pre-tested questionnaire (Table 1). Sources of information for eye donation were asked. The students got information from various sources like T.V. (24.08\%) Newspaper (23.35\%) Internet (27.73\%) (Table 2)71 (51.82 \%) students know that eyes should be enucleated within 6 hours of death (Table 3). 48 (35.03\%) students knew that cornea is used after eye donation (Table 3). 50 (36.49\%) students were knowing that kin of a deceased person can pledge eyes for donation even if the deceased person has not signed a will (Table 3) $77(56.20 \%)$ students were aware of the organ donation legislation act, while $59(43.06 \%)$ were unaware of it. (Table 4) $73(53.28 \%)$ students are ready to donate their close relative's eyes upon their untimely death, same time 17 (12.40\%) students are of the negative opinion to donate the eyes (Table 4).

$128(93.43 \%)$ students out of 137agreed about shortage of eye donors (Table 4).and120 (87.59\%) participants were willing for eye donation (Table 5). Reasons for willingness to donate eyes by the students were as mentioned in, namely, 85 (62.04 $\%)$ would like something positive from their death,15 $(10.94 \%)$ as a social commitment (Table 6). Reasons were given by the students for not willing to donate eyes were namely fear of misuse of eyes by $24(17.51 \%)$, do not want to be mutilated by 15 (10.94\%) (Table 7$)$.

\section{Questionnaire}

Arranged in table format as per suggestions by reviewer

\begin{tabular}{|l|l|l|}
\hline \multicolumn{1}{|c|}{ Questions } & \multicolumn{1}{|c|}{$\begin{array}{l}\text { Responses were } \\
\text { given by students }\end{array}$} & \multicolumn{1}{|c|}{$(\%)$} \\
\hline $\begin{array}{l}\text { 1. Which of the following sources gave } \\
\text { you information about Eye Donation? }\end{array}$ & a) Newspaper & $\begin{array}{l}32(23.35 \\
\%)\end{array}$ \\
\hline
\end{tabular}

\begin{tabular}{|c|c|c|}
\hline & $\begin{array}{l}\text { b) T.V. shows } \\
\text { c) Internet } \\
\text { d) Health } \\
\text { Professional } \\
\text { e) No one } \\
\text { particular } \\
\text { source }\end{array}$ & $\begin{array}{l}33(24.08 \%) \\
38(27.73 \%) \\
35(25.54 \%) \\
30(21.89 \%)\end{array}$ \\
\hline $\begin{array}{l}\text { 2. What do you understand by the term } \\
\text { "Keratoplasty"? }\end{array}$ & $\begin{array}{l}\text { a) Corneal } \\
\text { transplant } \\
\text { b) Retinal } \\
\text { transplant } \\
\text { c) Eye } \\
\text { transplant }\end{array}$ & $\begin{array}{l}77(56.20 \%) \\
43(31.86 \%) \\
18(13.13 \%)\end{array}$ \\
\hline $\begin{array}{l}\text { 3. The family of a deceased person can } \\
\text { pledge his/her eyes for donation even if the } \\
\text { person has not signed a will }\end{array}$ & $\begin{array}{l}\text { a) True } \\
\text { b) False }\end{array}$ & $\begin{array}{l}50(36.49 \%) \\
75(54.74 \%)\end{array}$ \\
\hline $\begin{array}{l}\text { 4. A single eye donation can be used for } \\
\text { multiple recipients. }\end{array}$ & $\begin{array}{l}\text { a) True } \\
\text { b) False }\end{array}$ & $\begin{array}{l}58(42.33 \%) \\
72(52.55 \%)\end{array}$ \\
\hline $\begin{array}{l}\text { 5. Within how many hours preferably, after } \\
\text { the death, eyes should be removed for eye } \\
\text { donation purposes? }\end{array}$ & $\begin{array}{l}\text { a) Within } 6 \text { hrs } \\
\text { b) Within } 24 \\
\text { hrs } \\
\text { c) Don't know }\end{array}$ & $\begin{array}{l}71(51.82 \%) \\
23(16.78 \%) \\
42(30.65 \%)\end{array}$ \\
\hline $\begin{array}{l}\text { 6. Do you feel that there is a necessity to } \\
\text { promote Eye Donation in this region? }\end{array}$ & $\begin{array}{l}\text { a) Yes strong } \\
\text { feel to promote } \\
\text { b) No need to } \\
\text { promote } \\
\text { c) Can't say }\end{array}$ & $\begin{array}{l}105(76.64 \%) \\
03(2.1 \%) \\
28(20.43 \%)\end{array}$ \\
\hline $\begin{array}{l}\text { 7. Who will be the best to promote Eye } \\
\text { Donation among the general public? }\end{array}$ & $\begin{array}{l}\text { a) Hospital } \\
\text { administration } \\
\text { b) Health care } \\
\text { providers } \\
\text { a) Govt. } \\
\text { b) NGOs }\end{array}$ & $\begin{array}{l}30(21.89 \%) \\
48(35.03 \%) \\
65(47.44 \%) \\
31(22.62 \%)\end{array}$ \\
\hline $\begin{array}{l}\text { 8. What do you exactly understand by } \\
\text { Enucleation of Eye? }\end{array}$ & $\begin{array}{l}\text { a) Complete } \\
\text { removal of the } \\
\text { eyeball } \\
\text { b) Only cornea } \\
\text { a) Only sclera }\end{array}$ & $\begin{array}{l}64(46.71 \%) \\
49(35.76 \%) \\
22(16.05 \%)\end{array}$ \\
\hline $\begin{array}{l}\text { 9. Are you aware that there is legislation } \\
\text { with regard to organ donation? }\end{array}$ & $\begin{array}{l}\text { b) Yes } \\
\text { c) No }\end{array}$ & $\begin{array}{l}77(56.20 \%) \\
59(43.06 \%)\end{array}$ \\
\hline $\begin{array}{l}\text { 10. What can be transplanted to the } \\
\text { recipient from donated eyes? }\end{array}$ & $\begin{array}{l}\text { a) Cornea } \\
\text { b) Retina \&Lens } \\
\text { c) Complete } \\
\text { eyeball } \\
\text { d) Don't know }\end{array}$ & $\begin{array}{l}48(35.03 \%) \\
32(23.35 \%) \\
35(25.54 \%) \\
32(23.35 \%)\end{array}$ \\
\hline $\begin{array}{l}\text { 11. What should the relative do after } \\
\text { informing to the Eye Bank about the } \\
\text { Donor's death? }\end{array}$ & $\begin{array}{l}\text { a) Keep the } \\
\text { donor's eyes } \\
\text { closed } \\
\text { b) keep fans in } \\
\text { the room off } \\
\text { c) Both a and b } \\
\text { d) don't know }\end{array}$ & $\begin{array}{l}22(16.05 \%) \\
01(0.72 \%) \\
49(35.76 \%) \\
64(46.71 \%)\end{array}$ \\
\hline
\end{tabular}




\begin{tabular}{|c|c|c|}
\hline $\begin{array}{l}\text { 12. Do you think "Eye } \\
\text { Donation" disfigures the } \\
\text { donor's face? }\end{array}$ & $\begin{array}{l}\text { a) Yes } \\
\text { b) No } \\
\text { a) Don't know }\end{array}$ & $\begin{array}{l}14(10.21 \%) \\
110(80.29 \%) \\
14(10.21 \%)\end{array}$ \\
\hline $\begin{array}{l}\text { 13. Would you donate a close } \\
\text { relative's Eyes upon his/her } \\
\text { untimely death? }\end{array}$ & $\begin{array}{l}\text { a) Yes } \\
\text { b) No } \\
\text { c) Can't say }\end{array}$ & $\begin{array}{l}73(53.28 \%) \\
17(12.40 \%) \\
47(34.30 \%)\end{array}$ \\
\hline $\begin{array}{l}\text { 14. Would you pledge your } \\
\text { eyes for Eye Donation? }\end{array}$ & $\begin{array}{l}\text { a) Yes } \\
\text { b) No }\end{array}$ & $\begin{array}{l}120(87.59 \%) \\
17(12.40 \%)\end{array}$ \\
\hline $\begin{array}{l}\text { 15. (If yes) what are your } \\
\text { reasons for opting for Eye } \\
\text { Donation? }\end{array}$ & $\begin{array}{l}\text { a) I would like something } \\
\text { positive to come from my } \\
\text { death } \\
\text { b) I can continue to live even } \\
\text { after my death } \\
\text { c) My religion supports organ } \\
\text { donation } \\
\text { d) Social commitment }\end{array}$ & $\begin{array}{l}85(62.04 \%) \\
26(18.97 \%) \\
03(2.1 \%) \\
15(10.94 \%)\end{array}$ \\
\hline $\begin{array}{l}\text { 16. (If No) What are your } \\
\text { reasons for not opting Eye } \\
\text { donation }\end{array}$ & $\begin{array}{l}\text { a) It is against my religious } \\
\text { belief } \\
\text { b) I fear that donated eyes } \\
\text { may be misused. } \\
\text { c) I live far away from the } \\
\text { closet center of Eye Bank } \\
\text { Eye retrieval center. } \\
\text { d) I do not wish to be } \\
\text { mutilated. }\end{array}$ & $\mid \begin{array}{l}03(2.1 \%) \\
24(17.51 \%) \\
00 \\
15(10.94 \%)\end{array}$ \\
\hline $\begin{array}{l}\text { 17. Do you think there is a } \\
\text { shortage of donors for Eye } \\
\text { Donation in India? }\end{array}$ & $\begin{array}{l}\text { a) Yes } \\
\text { b) No }\end{array}$ & $\begin{array}{l}128(93.43 \%) \\
06(4.37 \%)\end{array}$ \\
\hline
\end{tabular}

\section{Discussion}

Blindness from corneal disease is a major ophthalmic public health problem in India [11]. According to the estimation, there are to be 1.2 million corneal blind persons in India. There are an addition of $25,000-30,000$ cases of corneal blindness every year [12] Prevention is always better than cure. Measures of prevention of corneal blindness by giving comprehensive eye care from womb to tomb are cost-effective. But for some of the patient's corneal transplantation is the only treatment option for their visual rehabilitation. Corneal transplantation is the most common type of human transplant surgery done to regain the quality vision in the corneal blinds [13]. It is estimated that 270000 donor eyes are required to perform 100000 corneal transplants per year in India [14] This disparity in need and supply of donor human corneas poses a challenge to public health programs in India. To tackle this problem, the exact incidence, nature, and etiology of corneal blindness of the population under care should be known [15]. But illiteracy and rural residence are the main cause of ignorance about eye donation [16].
Knowledge, attitude, and actions are interrelated for making a decision. The decision-making process of a person is affected by culture, religion, and surroundings. Failure to pledge eyes could be due to lack of knowledge and not knowing the exact purpose of eye donation as well as religion. It may be construed that lack of awareness becomes a major obstacle in convincing and obtaining consent from the prospective donors for eye donation [17].

For this reason, it is imperative to increase the awareness regarding eye donation among the potential donors for the procurement of corneas. This can be achieved by sensitizing the new budding doctors. As the future healthcare providers, they can influence eye donation rates, to achieve this effectively, the knowledge, awareness, attitude of these medical students about eye donation should be tested

The use of print media like newspapers, magazines and today's social media platforms like Facebook, WhatsApp, Instagram, Twitter and television to increase the awareness in the general public regarding eye care and prevention of corneal blindness is not enough. It is a known fact that the mass media is playing a crucial role in the creation of awareness in the general public about the donation of eyes and organ donation. Newspapers also spread the message, but the human touch must be there to communicate, to participate, to promote, to sensitize and to answer the questions of the people.

In a study conducted by $\mathrm{M} \mathrm{K}$ Bharti et al major source of information about eye donation awareness was from mass media like TV (71\%) [18]. In the present study medical students have received information about eye donation from different sources. From T.V. $(24.08 \%)$ Newspaper (23.35\%) Internet $(27.73 \%)$.In another study by Gupta A.et al in students of nursing college Television was the most common source of information on eye donation for 145 (77.1\%) students, followed by the newspaper for $136 \quad(72.8 \%)$ students and magazines for 94 (50\%) students [19].

According to the study by $\mathrm{M} \mathrm{K}$ Bharti et al among students of the University of Malaya [18] (31\%) knows cornea is used for transplantation and. in the present study $48(35.03 \%)$ students out of 137 know the same.

Generally, the whole eyeball is removed from the eye donor. 
Meaning of the word "Enucleation" is the removal of the whole eyeball from the donor was known to $(40 \%)$ in the study by $M \mathrm{~K}$ Bharti et al [18] compared to 64 (46.71\%\%)of medical students out of 137 knowing the meaning in the present study. The only cornea can be removed from the donor and it has been practiced also in some parts of India.

Also, it was noted by Gupta A.et in students of nursing college 160 (85.1\%) of 188 were either willing or had already pledged to donate their eyes as compared to 120 (87.59\%) participants were willing for eye donation in the present study. AlL $159(84.5 \%)$ of 188 participants agreed that there is a shortage of eye donors [19] in another study by Singh MM 170 (94.4\%) of 180 participants agreed that there is shortage of eye donors [20] compared to 128 ( $93.43 \%$ ) students out of 137 agreed about shortage of eye donors in the present study.

In a study by Gawali A et al [21] $30 \%$ students knew that ideal time of donation was within 6 hours of death as compared to 71 (51.82\%) students out of 137 know that eyes should be enucleated within 6 hrs of death in the present study

A single eye donation can be used for multiple recipients was known to $(74.08 \%)$ students in a study by Mutukrihnan Vallinayagam [22] compared to $58(42.33 \%)$ students from the present study.

A study conducted at Hubli by Nekar MS [23] showed that $62.2 \%$ of medical students believed that the whole eyeball is transplanted, compared to 35 students $(25.54 \%)$ in the present study

The perception about whether there is a disfigurement of the face of a donor after eye donation reported in a study among nursing staff in a hospital in South India by Hegde V.[24] was as 8 $(14.5 \%)$ said yes, $39(70.9 \%)$ said no and $3(5.5 \%)$ said don't know out of 55, compared with the responses in the present study the responses were $14(10.21 \%)$ said yes, $110(80.29 \%)$ said no and $14(10.21 \%)$ said Don't know. Thus in the present study, $110(80.29 \%)$ students out of 137 were sure about non-disfigurement of face of the donor after eye donation In the same study by Hegde $\mathrm{V}$ [24] the main reason behind donating eyes among majority(76.3\%) was giving sight to the blind followed by nobility of the task (7.2\%). and in the present study the students response was something positive to come from the death 85 (62.04\%) Social commitment 15 (10.94\%).
In the present study, it was found that 73 (53.28\%) students responded to donate a close relative's Eyes upon his/her untimely death while37 (75.5 \%) were responded yes in a study by Dhaliwal $U$ [25]. To preserve the integrity of the cornea the eyes should be kept closed after death, The relative should Keep the donors eyes closed after informing to the Eye Bank this was response found in $6(12.2 \%)$ out of 49 medical students by Dhaliwal $U$ [25] and the response in the present study found was 22 (16.05 $\%)$, students

Limitation of the study: The sample size is less.

\section{Conclusion}

This study revealed that first year MBBS students were well aware of eye donations and most of them 120 ( $87.59 \%)$ out of 137 students were willing to pledge for eye donation. The reasons for not willing for eye donation include should be tackled while creating awareness about eye donation in the community. Medical students can be helpful as volunteers in eye donation campaigns and as counselors for eye donors. The level of knowledge, awareness, and attitude of a medical student is an important determinant in promoting eye donations.

Recommendation: In India, there is a strong need for developing effective means of procurement of corneas, to treat corneal blindness by keratoplasty. It is for that reason medical students can be of help to actively contribute to the eye donation campaign. The medical as motivators can raise awareness in the society to enhance eye donation. They can answer the queries about eye donation. They can participate to create awareness and motivate people to be eye donors.

\section{What does the study add to the existing Knowledge?}

In a country where there is a huge demand for corneas for corneal blind people, it is necessary for the promotion of eye donation activities for the procurement of more corneas. Medical students as future doctors of the society can be of help in educating, sensitizing, promoting the noble act of eye donation. This study highlights the awareness about eye donation in the majority of medical entrants (56.20 percent). Further, this study analyzes the sources of information about eye donation, and misconceptions prevalent in the minds of medical entrants. 
Future strategies can be built from this study to strengthen the eye donation movement in India.

\section{Author's contribution}

Dr. Rajesh Gotekar: Preparation of the Questionnaire, Arrangement for the conduction of test, collection of data, preparation of the manuscript for introduction, material methods and Compilation of References

Dr. Ajit K. Joshi: Data analysis, Preparation of results, Preparation of manuscript for discussion, correspondence with editor.

Acknowledgment: The authors express their sincere thanks to all the students for sparing their time to participate in this study.

\section{Reference}

01. Thylefors B, Negrel AD, Pararajasegaram R, Dadzie KY. Global data on blindness. Bull World Health Organization. 1995;73(1)115-121. [Crossref] [PubMed][Google Scholar]

02. Whitcher JP, Srinivasan M, Upadhyay MP. Corneal blindness- a global perspective. Bull World Health Organization. 2001;79(3)214-221. [Crossref] [PubMed][Google Scholar]

03. Pascolini D, Mariotti SP. Global estimates of visual impairment in 2010. $\mathrm{Br} \mathrm{J}$ Ophthalmol. 2012;96(5)614-618. Doi: 10.1136/bjophthalmol2011-300539 [Crossref][PubMed][Google Scholar]

04. Oliva MS, Schottman T, Gulati M. Turning the tide of corneal blindness. Indian J Ophthalmol. 2012;60(5)423-427. doi: 10.4103/03014738.100540 [Crossref][PubMed][Google Scholar]

05. Eze BI, Okoye O, Eze JN. Knowledge and Attitudes Regarding Eye Donation and Corneal Transplant- Medical Versus Nonmedical University Students in a Developing Country in Africa. Exp Clin Transplant. 2014;12(5)454-461. [Crossref] [PubMed][Google Scholar]

06. Kannan KA. Eye donation movement in India. J Indian Med Assoc. 1999;97(8)318-319. [Crossref] [PubMed][Google Scholar]

07. Mohan M. Survey of Blindness-India (19861989)- Summary Results. New Delhi- Programme for the Control of Blindness, Ministry of Health and Family Welfare, Government of India. 1992. [Crossref][PubMed][Google Scholar]
08. Kumara R. Eye Donation Awareness among the Students. Asian J of Biomedical and Pharmaceutical Sciences. 2016;53(6)37-38. [Crossref][PubMed] [Google Scholar]

09. Singh MM, Rahi M, Pagare D, Ingle GK. Medical Students perception on eye donation in Delhi. Indian J Ophthalmol. 2007;55;49-53. [Crossref] [PubMed][Google Scholar]

10. Dhabarde K, Hemangi T, Madan H. Awareness and perception regarding Eye donation. Community/Social Ophthalmology. Free Papers. [Crossref][PubMed][Google Scholar]

11. Gupta N, Vashist p, Ganger A, Tondon R, Gupta SK. Eye donation and eye banking in india. Natl Med J India. 2018;31(5)283-286. doi: 10.4103/0970258X.261189 [Crossref][PubMed][Google Scholar]

12. National Programme for Control of Blindness. Available from: [Article] [Crossref][PubMed][Google Scholar]

13. Yew YW, Saw SM, Pan JCH, Shen HM, Lwin M, Yew MS et al. Knowledge and beliefs on corneal donation in Singapore adults. $\mathrm{Br} \mathrm{J}$ Ophthalmol. 2005;89(7)835-840. doi: 10.1136\%2Fbjo.2004.057372 [Crossref][PubMed] [Google Scholar]

14. Saini JS. Realistic targets and strategies in eye banking. Indian J Ophthalmol. 1997;45(3)141-142. [Crossref][PubMed][Google Scholar]

15. Rekhi GS, Kulshreshtha OP. Common causes of blindness- A pilot study in Jaipur, Rajasthan. Indian J Ophthamol. 1991;39(3)108-111. [Crossref] [PubMed][Google Scholar]

16. Priyadarshini $B$, Srinivasan $M$, Padmavathi $A$, Selvam S, Saradha R, Nirmalan PK, et al. Awareness of eye donation in an adult population of southern India- A pilot study. Indian J Ophthalmol. 2003;51(1)101-104. [Crossref][PubMed][Google Scholar]

17. Krishnaiah S, Kovai V, Nutheti R, Shamanna B R, Thomas R, Rao GN. Awareness of eye donation in rural population in India. Indian $\mathrm{J}$ of Ophthalmol. 2004;52(1)73-78. [Crossref][PubMed][Google Scholar]

18. Bharti MK, Reddy SC, Tajunisah I, Ali NAM. Awareness and Knowledge on Eye Donation among University Students. Med J Malaysia. 2009;64(1)4145. [Crossref][PubMed][Google Scholar] 
19. Gupta A, Jain S, Jain T, Gupta K. Awareness and perception regarding eye donation in students of $a$ nursing college in Bangalore. Indian J Community Med. 2009;34(2)122-125. doi: 10.4103/09700218.51235 [Crossref][PubMed][Google Scholar]

20. Singh MM, Manju R, Deepti P, Ingle GK. Medical students' perception on eye donation in Delhi. Indian J Ophthalmol. 2007;55(1)49-53. doi: 10.4103/0301-4738.29495 [Crossref][PubMed] [Google Scholar]

21. Gawali A, Dase R, Pawar K Quadriu. Awareness and Knowledge Regarding Eye Donation in Students of Medical Colleges in Aurangabad. Int J Curr Med Appl Sci. 2014;2(1)9-13. [Crossref][PubMed] [Google Scholar]

22. Muthukrishnan V, Pranav S, Kumar, Krishnamoorthy J, Arumugam R. A Study on Eye Donation Awareness Among Medical and Engineering Students in Puducherry. Delhi J Ophthalmol. 2017. doi: 10.7869/djo.285 [Crossref] [PubMed][Google Scholar]
23. Nekar MS, Lokare L, Gokhale SA, Godbole M, Mulkipatil SY, Mahesh V. Awareness Of Eye Donation Among College Students Of Hubli City, Karnataka. Indian J Biomed Res. 2012;3(4)201-204. doi: 10.7439/ijbr.v3i4.415 [Crossref][PubMed][Google Scholar]

24. Hegde V, Rashmi S, Pavithra S. Awareness about eye donation among nursing staff in a hospital in South India- A questionnaire based study. Ind J Clin Experiment Ophthalmol. 2019;5(4)570-573. doi: 10.18231/j.ijceo.2019.130 [Crossref][PubMed][Google Scholar]

25. Dhaliwal U. Enhancing eye donation rates, Training students to be motivators. Ind J Ophthalmol. 2002;50(3)209. [Crossref][PubMed] [Google Scholar] 